\title{
A Comprehensive Review of Literature on Individual Cultural Intelligence
}

\author{
Ying Zhang \\ 1. School of Management and Marketing \\ Charles Sturt University \\ Wagga Wagga, Australia \\ 2. International Business School \\ Yunnan University of Finance and Economics \\ Kunming, China \\ angie@ynufe.edu.cn \\ Bingqing Ding \\ International Business School \\ Yunnan University of Finance and Economics
}

\author{
Kunming, China \\ 1446202654@qq.com
}

Peng Peng

International Business School

Yunnan University of Finance and Economics

Kunming, China

1798511156@qq.com

\author{
Antony Bush* \\ School of Management and Marketing \\ Charles Sturt University \\ Wagga Wagga, Australia \\ abush@csu.edu.au
}

\begin{abstract}
Cultural differences create the need for crossborder employees who are culturally intelligent. This research reviews recent literature on components of a multi-dimensional model of Cultural intelligence, its conceptualization, measurement and distinction from other types of intelligence. The implications justify the importance of identifying the individual differences in cultural intelligence and understanding them is important to build up successful cross-cultural transitions for the purpose of effective international human resource management in the host country environment.
\end{abstract}

Keywords - cross-cultural transitions; international human resource management; cultural intelligence

\section{INTRODUCTION}

As a fledgling research area, CQ reflects a broad and deep capability for comprehending the new surroundings and holds great promise for potential improvements to expatriation [8]. Basically, CQ draws from various disciplines including crosscultural psychology, anthropology, and sociology. Its conceptualization is based on several valued theories in the psychological sciences including Stryker's Identity Theory [1]; Erez and Earley's Cultural Self-Representation Theory [2], Bandura's Social Learning Theory and Self-efficacy theories [3-4], and Triandis's work in Analysis of Subject Culture [2425]. Researchers have begun to explore the nature of CQ over last ten years[3][7][21]. For example, Soon Ang has established a research centre in Singapore for the study of cultural intelligence with its U.S. counterpart, the Cultural Intelligence Centre based in Michigan.

\section{THE NATURE OF CQ}

Culture and intelligence are closely intertwined [19-20]. For instance, attitudes and behaviours that are considered

\footnotetext{
* Corresponding author
}

appropriate and highly intelligent in one culture may be improper and inappropriate in another. The first definition of intelligence derives from the study of Francis Galton in 1879 as an intellectual ability that could be measured by mental tests. Intelligence quotient (IQ) tests are broadly used in educational, business, and military settings due to their efficacy in predicting behaviours of different individuals. IQ is found to be significantly correlated with many important social outcomes, such as successful training, more years of education, higher status jobs, higher income and performance; and it is an ideal predictor of successful job performance [15] There is now growing awareness that supports Sternberg and Detterman's (1986) remark that intelligence should be applied to research areas beyond the classroom [20].

The increasing attention given to intelligence research has led to the categorization of intelligence into various domains, each focusing on a specific intelligence aspect. Going beyond the book-learning academic skills of IQ, Earley and Mosakowski [7] described cultural intelligence as a concept that focuses primarily on a specific domain of intelligence, that is, intelligence in intercultural settings. To elucidate the nature of $\mathrm{CQ}$, the following discussion focuses on the clarification of differences between $\mathrm{CQ}$ and potentially confounding concepts of (i) emotional intelligence [5], (ii) social intelligence [14], and (iii) personality.

The cognitive and behavioural aspects of CQ share similarity with emotional intelligence (EQ) in that they both describe individual differences about how people may conform and be flexible according to situation demands and social cues. Earley and Mosakowski [7] explain that, unlike CQ, EQ does not include adaptation across cultures. EQ refers to the ability to perceive emotions, and to generate and regulate emotions for effective social interactions [34]. However, the ability to encode and decode emotions in the 
home culture does not automatically transfer to unfamiliar cultures, because what is meaningful in one culture may not apply in another [9]. That is, an emotionally intelligent person in one cultural context may not be emotionally intelligent in another. Individuals who have high levels of EQ but do not have cultural sensitivity may suffer from cross-cultural adaptation due to culturally inappropriate understanding and interpretation of culture-specific situational information. In contrast, $\mathrm{CQ}$ is a general set of capabilities that have relevance to situations characterized by cultural diversity [1112]. Indeed, though waiting to be empirically tested, the current study proposes that $\mathrm{CQ}$ may have a negative relationship with EQ; that is, emotionally intelligent individuals in their home cultures can be entirely incapable at functioning across new cultural settings[13], because high levels of EQ reflect deep immersion in one's home culture, but strong home country cultural identity would not help open attitudes, and is likely to hinder the development of CQ.

A second concept that can be a source of confusion is social intelligence (SQ). SQ is defined as an ability to understand the feelings, thoughts and behaviours in interpersonal situations and to act appropriately on the basis of this understanding [27]. Socially intelligent people are able to easily adapt their behaviour to a variety of social situations [27]. However, because rules for social interactions vary from culture to culture, SQ does not necessarily translate into effective interaction [7]. That is, high SQ individuals who are able to interact effectively with others in a particular culture may not necessarily be able to do so in a different cultural environment characterized by a different set of social norms[16-18], but high CQ individuals are able to interact in culturally diverse settings. SQ is culturally bound [35], and because cultures differ, SQ cannot adequately explain effective interpersonal behaviour across cultures [7].

Finally, personality can be another source of confusion. Despite of criticism [28], the Big Five personality traits [29] extroversion, agreeableness, conscientiousness, neuroticism, and openness) is the prominent measurement construct of personality for use in cross-cultural adjustment research. Given that personality affects choice of behaviours and experiences, Ang et al. (2006) conducted a quantitative study to examine the relationship between five personality traits and the four-dimensional model of cultural intelligence [31]. They found that only openness to experience was significantly related to all four dimensions of CQ. The personality trait of openness to experience was defined as being imaginative, cultured, creative, original, broad-minded, intelligent, and artistically sensitive [29]. Personality traits describe what a person typically does across time and situations [29], but CQ focuses on a particular type of individual capability, describing what a person can do to be effective in culturally diverse settings [19-20]. Thus, they are totally different concepts. Grounding CQ as a form of intelligence allows precision about the nature of CQ from a set of relatively confusing concepts that can be further enhanced and refined over time.

In sum, EQ and SQ describe individuals' capability to manage emotions and interpersonal situations in a common cultural setting. In other words, EQ and SQ lack a cultural component. Therefore, they are less informative, and hence less predictive of an individual's cognition, motivation, and behaviour in culturally diverse settings [9]. Since the norms and value systems for social interaction vary from culture to culture, it is unlikely that individuals with high EQ and SQ in one culture will effectively translate these abilities automatically into different cultural settings [7]. CQ conceptually overlaps with EQ and SQ in that they complement intelligence, and all are important for an individual to effectively function successfully at work and in various social settings and in personal relationships. CQ complements IQ by describing individual variability in coping with diversity and functioning in new cultural settings. CQ shares some attributes with personality and other intelligence concepts, yet is distinct in the nature of abilities from these other forms of intelligence, because CQ deals specifically with cognition, motivation and behaviour in cross-cultural settings, and is a general set of capabilities with relevance to situations characterized by cultural diversity [30].

\section{CONCEPTUALIZATION OF FouR-Dimensional CQ}

Essentially, CQ is grounded in the theory of multiple intelligences [2], and is conceptualized as a multi-dimensional model [9]. Earley (2002) illustrates that CQ resides in three dimensions: the body, the heart, and the head. Similarly [3], Thomas and Inkson (2004) also view CQ as having three components [21: knowledge, mindfulness, and a behavioural component. Earley and Ang (2003) further advanced four dimensions that constitute cultural intelligence (as shown in figure 1) [9]: (i) meta-cognitive, (ii) cognitive, (iii) motivational, and (iv) behavioural CQ. These four dimensions of CQ reflect the existing observation of intelligence [20] as a complex, multi-facet individual attribute and will now be described in detail.

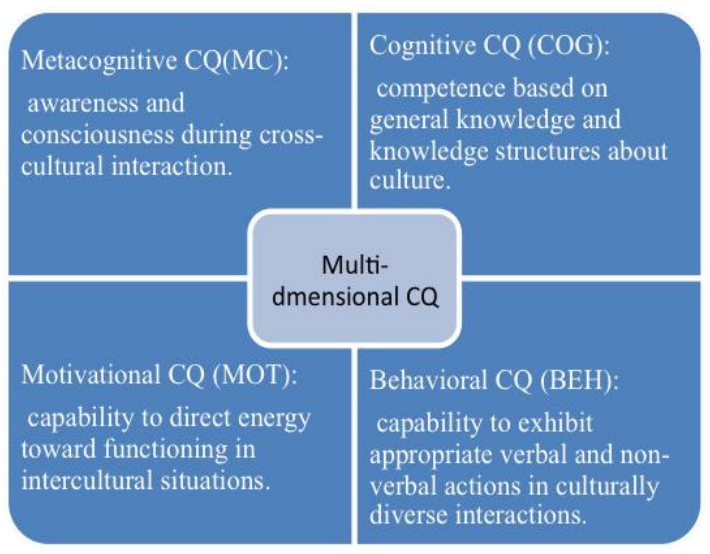

Fig. 1. Demonstration of Dimensions of Cultural Intelligence

Source: adapted from Earley and Ang (2003), Earley and Mosakowski (2004) and Ang et al. (2007)[9][32-33]

\section{A. Meta-cognitive $C Q$}

Meta-cognition is a higher level ability that concerns individuals' knowledge and strategy monitoring, controlling and using the cognitive knowledge that one possesses [6]. The concept stemmed from cognitive psychology studies, has been referred to as the "thinking about thinking" [36], or "cognition 
about cognition" [6]. According to Flavell (1979), metacognition has two broad elements [36], including (i) metacognitive knowledge, i.e. what and how to deal with knowledge gained under a variety of circumstances; and (ii) meta-cognitive experience, i.e. what and how to incorporate relevant experiences as a general guide for future interactions.

The important implication of meta-cognition towards cross-cultural adjustment lies in that, it provides persistence and attention to detail of unfamiliar verbal and nonverbal cues [6], and encompasses strategizing before cross-cultural interaction, checking presumptions during an encounter and adjusting mental maps when experiences diverge from expectations [33]. Individuals with greater meta-cognitive CQ should be better able to understand, interpret, and act according to these cues, thus meta-cognition is a critical aspect of CQ [13].

There are three key aspects of meta-cognitive CQ: planning, self-monitoring and the use of cognitive strategies [13]. In order to develop planning, individuals must establish a goal and develop a plan to accomplish it. This process entails grabbing power over cognitive actions and monitoring one's thinking [6].

Self-monitoring requires analyzing one's own state of capability and being aware of that state, determining the need for future practice to master a skill or manage a situation [13] The self-monitoring aspect is important to achieve high levels of CQ because it helps with developing competence and avoiding the appearance of incompetence [3].

Finally, the use of cognitive strategies in meta-cognition involves the knowledge of self in relation to approaches that the individual could use to accomplish possible strategies, the knowledge of general strategies to make interaction decisions, the knowledge of when and how to use certain strategies in certain situations, and the knowledge of how these various strategies will be effective [3][13].

Planning, self-monitoring, and using cognitive strategies in the initial stage of the cross-cultural encounter intertwine into the meta-cognitive aspect of CQ model, through which individuals assess self and the situation in an unfamiliar situation and prepare behaviours and strategies that can be understood and managed.

\section{B. Cognitive $C Q$}

The cognitive facet refers to the knowledge of a new culture that individuals may obtain and the understanding that they build up through a range of cues [9-10] explain that cognition involves "knowing 'about' things", "knowing 'how to do' things", "knowing the 'why and when' of things"; and it concerns the information-processing aspects of intelligence based on Self-concept Theory.

According to Markus and Wurf, the self is a person's mental representation of her own personality, social identity, and social roles. Importantly, Earley and Ang (2003) assert that knowing oneself is not sufficient for high $\mathrm{CQ}$ as awareness does not guarantee flexibility [9]; instead, managing self-concept flexibly and strong reasoning skills are important for high level CQ, because understanding new cultures may require abandoning pre-existing conceptualizations of oneself and pre-existing comprehensions of how and why others function as they do [3].

Cognitive abilities of CQ are shown in ways of integrating new messages and information, and using self-concept to comprehend new cultural encounters [3]. A culturally intelligent person could generate an accurate mapping of the social situation to function effectively, because she or he knows "what culture is, how cultures vary, and how culture affects behaviour" [21. This entails a general but wide-ranging foundation of knowledge about cultures and societies including political, economic, religious systems, and social relationships.

\section{Motivational CQ}

The third aspect of CQ, motivation, refers to individuals' willingness to face and engage the new culture and their inward desire to persevere when faced with difficult situations [13]. Motivation has been considered as a vital aspect of cross-cultural adjustment, as Earley (2002) asserts that if the motivational facet of cultural intelligence is weak, adjustment will not occur [3]. The close relationship between motivation and culture has been noted in various studies (e.g. Adler, 2002 Smith \& Bond, 1999). Merely cognitive understanding of the new culture and possessing requisite skills do not qualify for effective cross-cultural adjustment, and enough motivation is needed to engage successful cross-cultural interaction [3].

Based on Social Learning Theory [25], Goal-Setting Theory (Locke \& Latham, 1990) and Cultural SelfRepresentation Theory [2], Earley and Ang (2003) describe three critical components of the motivational aspect of CQ [9] (i) persistence or maintenance of norms and values, (ii) selfefficacy, and (iii) goal-setting. According to Social Learning Theory [25], motivation is generated when cognitive representations of expected outcomes build a mental picture of a desired result. As home and host culture vary, presumably, individuals with strong desires to maintain familiarity will not be motivated to change behaviour (Williams, 2008). Therefore, high-level inclination to maintain home country norms and values would result in lower level persistence in the face of difficulties, uncertainty, and challenges in the host cultural environment. Individuals who lack of persistence in new cultures would easily retreat after experiencing early adjustment difficulties [3].

Second, Self-representation Theory [2] suggests that individuals gain self-enhancement, self-efficacy and a feeling of importance from social contacts and interactions. The concept of self-efficacy refers to "a judgment of one's capability to accomplish a certain level of performance" [25] This judgment is a key determinant of motivation as individuals are inclined to evade tasks and situations they believe go beyond their capabilities and are likely to accept or choose tasks and situations they believe are under control [2]. Self-efficacy plays an important role in CQ because successful intercultural interaction is based on a person's sense of efficacy for social discourse in a novel setting. Individuals who doubt their own abilities to understand and 
interact in new cultures are liable to "disengage after experiencing early failures" [3]. Therefore, cultural intelligence reflects self-concept; and it directs and motivates adjustment to new cultural surroundings.

Third, goal-setting provides purpose, direction, a sense of achievement, and feedback concerning successful accomplishment of tasks and interaction [26][37]. Goalsetting is a critical component of the motivational facet of CQ because the immediate benefit of setting goals is to guide adaptation strategies in productive directions, to solidify personal commitment to adjusting, and to persist in the face of failure or confusion [9]. Individuals without goals would lack a basis for self-evaluation of task completion, because it is the goals and objectives that offer the obligation and criteria for proper completion [26]. The motivational theories suggest that individuals' behaviours and actions are merely out of motivation, which makes it a particularly noteworthy aspect.

\section{Behavioural $C Q$}

The overall concept of CQ is more than thinking about thinking (meta-cognitive), knowing what and how to do (cognitive), and having the willingness to engage and persevere (motivational). It also requires individuals to have "a well developed repertoire of behaviours" [21], and to be able to choose appropriate behaviours from this repertoire and exert culturally appropriate behaviours in new cultural circumstances at ease [3]. Thus, the behavioural component of CQ is defined as the ability "to generate the behaviours needed to reflect cognition and motivation" [9].

Behavioural CQ is the only observable aspect of CQ to the interlocutor [9]. The most salient aspect of CQ is behavioural CQ since meta-cognition, cognition, and motivation do not necessarily translate into culturally proper behaviours such as self-presentation, linguistic performance and nonverbal behaviours. It focuses on individual capabilities at the action level and reflects individual capability to exhibit appropriate verbal and nonverbal actions in culturally diverse interactions [21]. In other words, possessing proper meta-cognitive, cognitive and motivational elements does not necessarily ensure behavioural CQ, and behaviours that people enact in a new cultural environment do not always reflect meta-cognition, cognition and motivation that are not perceivable. Selfpresentation and Impression Management Theory (Goffman, 1959) contribute to the explanations of the behavioural CQ framework. According to Goffman (1959), making a good first impression in an interaction requires an individual to attend, not only to verbal and nonverbal communications, but also to kinesics, facial expressions, proxemics, and social clues, which vary by culture. Earley and Peterson (2004) cited instances in which a person may know and wish to enact a culturally appropriate behaviour but cannot do so because of some deepset reservations [13]. Components of behavioural CQ encompass elements of self-presentation, i.e. conscious or unconscious attempts to control self-images; language production, i.e. foreign language ability; and nonverbal messages, i.e. communication through body language [9]. That is, people with high-level behavioural CQ are likely to be capable of exerting situational appropriate behaviours based on their broad range of verbal and non-verbal capabilities, such as presenting culturally appropriate words, tone, gestures, facial expressions and body language.

Importantly, Earley (2002) explained the potential effect of mimicry to high-level behavioural CQ [3]. Research suggests that actual mimicking of interlocutor's behaviour, even if done unconsciously or mechanically, leads to greater satisfaction with the interaction. According to Earley (2002), a person high in behavioural CQ is a talented mimic who can integrate and imitate the cues and behaviours they learned through observing others [3]. If mimicry is adopted with intent then it constitutes a type of cognitive strategy [3]. That is, mimicry, though subtle and unconscious, brings a number of positive benefits in a social encounter and can be used as a strategy for facilitating interaction. A high CQ person is a gifted imitator even if such mimicry is conducted unconsciously.

To sum, the overall conceptualization of the fourdimensional CQ model [9] has received very few criticisms. The most common objections have been summarized in Hampden-Turner and Trompenaars [38]. According to Hampden-Turner and Trompenaars [38], the critiques against cultural intelligence mainly claim that (i) cultures are said to be entirely relative in their values, so holding one culture to be more intelligent than another is discriminatory; (ii) cultural studies are said to be a form of postmodernism, whereas to have one central definition of culture is modernist - an imposition of our own dominant beliefs; and (iii) attempts to categorize cultures are said to be crude stereotypes. In their argument, Hampden-Turner and Trompenaars (2006) addressed each one of these criticisms and defended the legitimacy of the CQ concept in management research [38]. It is important to note that all of those objections come from researchers who examine cultural intelligence as a cultural factor at the macro level rather than at the micro individual level. The most influential work in the development of CQ conceptualization and its applications are summarized in table 1.

TABLE I. CONCEPTUALIZATION AND APPLiCATIONS OF CULTURAL INTELLIGENCE

\begin{tabular}{|c|c|c|c|}
\hline Study & Conceptualization of CQ & Constituent Dimensions & Applications \\
\hline $\begin{array}{l}\text { Earley, 2002; } \\
\text { Earley and Ang, } \\
2003[8-9]\end{array}$ & $\begin{array}{l}\text { Conceptualized as an individual capability to adapt } \\
\text { effectively to new cultural contexts. }\end{array}$ & $\begin{array}{ll}- & \text { Mind-Cognitive (including } \\
\text { meta-cognitive dimension) } \\
\text { - } & \text { Heart-Motivational } \\
\text { - } & \text { Body-Behavioural }\end{array}$ & $\begin{array}{ll} & \text { Global assignment } \\
\text { - } & \text { Success } \\
\text { - } & \text { Diversity assignments } \\
& \text { Training methods }\end{array}$ \\
\hline $\begin{array}{l}\text { Thomas and } \\
\text { Inkson, } 2003\end{array}$ & $\begin{array}{l}\text { Conceptualized as abilities involving understanding the } \\
\text { fundamentals of intercultural interaction, developing a } \\
\text { mindful approach to intercultural interactions, and building }\end{array}$ & $\begin{array}{ll} & \text { Knowledge } \\
- & \text { Mindfulness } \\
\text { - } & \text { Behavioural Skills }\end{array}$ & $\begin{array}{l}\text { - } \quad \text { Cross-cultural decision } \\
\text { making } \\
\text { - Cross cultural }\end{array}$ \\
\hline
\end{tabular}




\begin{tabular}{|c|c|c|c|}
\hline & $\begin{array}{l}\text { adaptive skills and a repertoire of behaviour so that one is } \\
\text { effective in different intercultural situations. }\end{array}$ & & communication \\
\hline $\begin{array}{l}\text { Earley and } \\
\text { Mosakowski, } \\
2004[7]\end{array}$ & $\begin{array}{l}\text { Conceptualized as a seemingly natural ability to interpret } \\
\text { someone's unfamiliar and ambiguous gestures in just the } \\
\text { way that person's compatriots and colleagues would, even to } \\
\text { mirror them. }\end{array}$ & $\begin{array}{ll}- & \text { Cognitive } \\
- & \text { Physical } \\
- & \text { Emotional/Motivational }\end{array}$ & $\begin{array}{l}\text { - } \quad \text { Appropriate behaviours in } \\
\text { new cultures }\end{array}$ \\
\hline $\begin{array}{l}\text { Earley and } \\
\text { Peterson, } 2004 \\
{[13]}\end{array}$ & $\begin{array}{l}\text { Conceptualized as a person's capability to gather, interpret, } \\
\text { and act upon these radically different cues to function } \\
\text { effectively across cultural settings or in a multicultural } \\
\text { situation. }\end{array}$ & $\begin{array}{ll}- & \text { Meta-cognitive } \\
- & \text { Cognitive } \\
- & \text { Motivation } \\
\text { - } & \text { Behaviour } \\
\end{array}$ & $\begin{array}{ll}\text { - } & \text { Intercultural training } \\
\text { - } & \text { Multinational teams }\end{array}$ \\
\hline $\begin{array}{l}\text { Earley, Ang and } \\
\text { Tan, } 2006[10]\end{array}$ & $\begin{array}{l}\text { Conceptualized as a person's capability for successful } \\
\text { adaptation to new cultural settings, unfamiliar settings } \\
\text { attributable to cultural context. }\end{array}$ & $\begin{array}{ll} & \text { Cultural strategic thinking } \\
\text { - } & \text { Motivation } \\
\text { - } & \text { Behaviour }\end{array}$ & $\begin{array}{ll}- & \text { Diversity assignments } \\
\text { - } & \text { Global work assignments } \\
\text { - } & \text { Global teams }\end{array}$ \\
\hline Thomas & $\begin{array}{l}\text { Conceptualized as the ability to interact effectively with } \\
\text { people who are culturally different. }\end{array}$ & $\begin{array}{ll} & \text { Knowledge } \\
\text { - } & \text { Mindfulness } \\
\text { - } & \text { Behaviour } \\
\end{array}$ & $\begin{array}{ll}\text { - } & \text { Development } \\
\text { - } & \text { Assessment }\end{array}$ \\
\hline $\begin{array}{l}\text { Ang et al., } \\
2007[37]\end{array}$ & $\begin{array}{l}\text { Conceptualized as an individual's capability to function and } \\
\text { manage effectively in culturally diverse settings. }\end{array}$ & $\begin{array}{ll}- & \text { Meta-cognition } \\
- & \text { Cognition } \\
- & \text { Motivation } \\
- & \text { Behaviour }\end{array}$ & $\begin{array}{ll}\text { - } & \text { Cultural judgment and } \\
& \text { decision making } \\
\text { - } & \text { Cultural adaptation } \\
\text { - } & \text { Task performance }\end{array}$ \\
\hline
\end{tabular}

\section{EMPIRICAL STUDIES ON CQ}

As CQ is construct developed in the last decade, there have been so far a limited number of empirical studies; indications, however, point to an increasing predictive validity. Empirical studies on CQ mainly concentrate on its relationships with five personality traits [31], cultural judgment, decision-making and task performance, cultural adjustment, cross-cultural experiences and need for control [39], multi-cultural teams in cross-border business [40], and international non-work experiences and preferred organizational culture [41].

To better understand how the four CQ factors affect individuals in new cultural environments, previous empirical studies on CQ, with a brief description of issues addressed and not addressed are summarized in table 2 . The findings from these representative studies confirm that $\mathrm{CQ}$, as an individual level construct, is associated with a wide range of personal, professional and outcome variables. The predictive validity of CQ has been demonstrated to exist in many samples, including undergraduates, individuals, foreign professionals, international executives; using many criteria, for example, cultural judgment tasks, quality of business proposals developed through collaborative intercultural interaction, adjustment in foreign assignments; and over and beyond other constructs, such as demographics, intelligence, and international experience.

TABLE II. SUMMARY OF EMPIRICAL StUdies on CUltural INTELLIGENCE

\begin{tabular}{|c|c|c|c|c|}
\hline Study & Context & $\begin{array}{c}\text { Data Analysis } \\
\text { Technique }\end{array}$ & Description of work & Issues not covered \\
\hline $\begin{array}{l}\text { Ang et al. } \\
(2006)[31 \\
]\end{array}$ & $\begin{array}{l}338 \text { business } \\
\text { undergraduates }\end{array}$ & $\begin{array}{l}\text { Hierarchical } \\
\text { regression } \\
\text { analysis }\end{array}$ & $\begin{array}{l}\text {-Examined the relationships between CQ and five personality } \\
\text { traits. } \\
\text {-Significant relationships were found between } \\
\text { (i) conscientiousness and meta-cognitive CQ; } \\
\text { (ii) agreeableness and emotional stability with behavioural CQ; } \\
\text { (iii) extraversion with cognitive, motivational, and behavioural } \\
\text { CQ; } \\
\text { (iv) openness with all four factors of CQ. }\end{array}$ & $\begin{array}{l}\text { The study is the first to } \\
\text { examine personality and CQ, } \\
\text { and the model is incomplete. } \\
\text { Moderators of the } \\
\text { relationships to further } \\
\text { specify boundary conditions } \\
\text { for the findings are absent. }\end{array}$ \\
\hline $\begin{array}{l}\text { Templer, } \\
\text { Tay, and } \\
\text { Chandras } \\
\text { ekar } \\
(2006)\end{array}$ & $\begin{array}{l}157 \text { global } \\
\text { professionals in } \\
\text { Singapore }\end{array}$ & $\begin{array}{l}\text { Hierarchical } \\
\text { regression } \\
\text { analysis }\end{array}$ & $\begin{array}{l}\text {-Examined the relationships between motivational CQ and socio- } \\
\text { cultural adjustment. } \\
\text {-Positive relationships were found between motivational CQ and } \\
\text { socio-cultural adjustment (i.e. work adjustment, general living } \\
\text { condition adjustment, and host country international adjustment). }\end{array}$ & $\begin{array}{l}\text {-Other three dimensions of } \\
\text { CQ not covered. } \\
\text {-Psycho-Cultural adjustment } \\
\text { outcome not covered. } \\
\text {-More host countries in } \\
\text { broader contexts are needed } \\
\text { to for further validate the } \\
\text { findings. }\end{array}$ \\
\hline $\begin{array}{l}\text { Ang et al. } \\
(2007)[32 \\
]\end{array}$ & $\begin{array}{l}\text { Study1: } 593 \\
\text { undergraduates } \\
\text { from the U.S. } \\
\text { and Singapore; } \\
\text { Study } 2: 98 \\
\text { international } \\
\text { managers } \\
\text { temporarily in } \\
\text { Singapore; } \\
\text { Study } 3: 103\end{array}$ & $\begin{array}{l}\text { Hierarchical } \\
\text { regression } \\
\text { analysis }\end{array}$ & $\begin{array}{l}\text {-Examined the relationship between the four dimensions of CQ } \\
\text { and three intercultural effectiveness outcomes (i.e., cultural } \\
\text { judgment and decision making, task performance, and cultural } \\
\text { adaptation). } \\
\text {-Meta-cognitive CQ and cognitive CQ were found to be predictors } \\
\text { of cultural judgment and decision-making. } \\
\text {-Motivational CQ and behavioural CQ predicted cultural } \\
\text { adaptation. } \\
\text {-Meta-cognitive CQ and behavioural CQ predicted task } \\
\text { performance. }\end{array}$ & $\begin{array}{l}\text { - Individual level predictors } \\
\text { not covered. } \\
\text {-Consistency of design was } \\
\text { sacrificed for breadth of } \\
\text { findings } \\
\text { - Ignored other antecedent } \\
\text { variables for other aspects of } \\
\text { cultural adaptation. }\end{array}$ \\
\hline
\end{tabular}




\begin{tabular}{|c|c|c|c|c|}
\hline & $\begin{array}{l}\text { foreign } \\
\text { professionals in } \\
\text { Singapore. } \\
\end{array}$ & & -Cross-validated CQS. & \\
\hline $\begin{array}{l}\text { Tarique } \\
\text { and } \\
\text { Takeuchi } \\
(2008)\end{array}$ & $\begin{array}{l}221 \\
\text { undergraduates } \\
\text { in an American } \\
\text { university }\end{array}$ & $\begin{array}{l}\text { Hierarchical } \\
\text { regression } \\
\text { analysis }\end{array}$ & $\begin{array}{l}\text {-Examined the relationships between CQ and international non- } \\
\text { work experience. } \\
\text { - Higher numbers of non-work experience were associated with } \\
\text { higher levels of CQ. }\end{array}$ & $\begin{array}{l}\text { More different cultural } \\
\text { contexts should enhance the } \\
\text { generalizability of findings. }\end{array}$ \\
\hline $\begin{array}{l}\text { Tay et } \\
\text { al.'s } \\
(2008)\end{array}$ & $\begin{array}{l}491 \text { business } \\
\text { travellers in } \\
\text { Brazil, } \\
\text { Singapore, and } \\
\text { Israel }\end{array}$ & $\begin{array}{l}\text { Hierarchical } \\
\text { regression } \\
\text { analysis }\end{array}$ & $\begin{array}{l}\text { - Examined the relationships between CQ and multicultural } \\
\text { experiences and need for control. } \\
\text {-Multicultural experiences were positively related to cognitive CQ. } \\
\text {-Need for control was positively related to all four factors of CQ. }\end{array}$ & $\begin{array}{l}\text { Influence of multicultural } \\
\text { experiences and need for } \\
\text { control have been examined } \\
\text { rather than overall cross- } \\
\text { cultural adjustment. }\end{array}$ \\
\hline $\begin{array}{l}\text { Shokef } \\
\text { and Erez's } \\
(2008) \\
{[40]}\end{array}$ & $\begin{array}{l}191 \text { MBA } \\
\text { students in } \\
\text { Israel, Hong } \\
\text { Kong, Spain, } \\
\text { South Korea, } \\
\text { and the U.S. }\end{array}$ & $\begin{array}{l}\text { Hierarchical } \\
\text { regression } \\
\text { analysis }\end{array}$ & $\begin{array}{l}\text {-Examined the affects of working in multicultural teams on CQ } \\
\text { and global identity. } \\
\text {-Working in multicultural teams enhanced the development of } \\
\text { meta-cognitive, behavioural, and motivational CQ, and global } \\
\text { identity. }\end{array}$ & $\begin{array}{l}\text { As the scope of study was } \\
\text { large, there is no narrow } \\
\text { focus on multicultural teams. }\end{array}$ \\
\hline $\begin{array}{l}\text { Balogh et } \\
\text { al. } \\
(2011)[41 \\
\text { ] }\end{array}$ & $\begin{array}{l}1242 \text { students } \\
\text { in Hungary }\end{array}$ & $\begin{array}{l}\text { Hierarchical } \\
\text { regression } \\
\text { analysis }\end{array}$ & $\begin{array}{l}\text {-Examined the relationships between CQ levels and desired } \\
\text { organizational culture. } \\
\text {-Students with higher levels of CQ preferred to work in an } \\
\text { organization with a culture of adhocracy rather than hierarchical } \\
\text { culture. } \\
\text {-Students with low cultural intelligence prefer hierarchical } \\
\text { organizations that value stability, predictability and control. }\end{array}$ & $\begin{array}{l}\text { The study treats CQ as a fixed } \\
\text { personal characteristic, and } \\
\text { neglects the development of } \\
\text { CQ and change of CQ levels } \\
\text { throughout lifetime } \\
\text { experience. }\end{array}$ \\
\hline $\begin{array}{l}\text { Ramalu et } \\
\text { al. (2011) }\end{array}$ & $\begin{array}{l}332 \text { individuals } \\
\text { in Malaysia }\end{array}$ & $\begin{array}{l}\text { Hierarchical } \\
\text { regression } \\
\text { analysis }\end{array}$ & $\begin{array}{l}\text {-Greater general adjustment is related to greater motivational and } \\
\text { meta-cognitive CQ. } \\
\text {-Interaction adjustment is associated with greater motivational, } \\
\text { meta- cognitive and cognitive CQ. } \\
\text {-Greater work adjustment is related to greater motivational CQ. } \\
\text {-Motivational component of CQ is the only dimensions of CQ that } \\
\text { is significantly related to all three dimensions of adjustment. }\end{array}$ & $\begin{array}{l}\text { The study limits the } \\
\text { examination of cross-cultural } \\
\text { adjustment to socio-cultural } \\
\text { adjustment alone. Psycho- } \\
\text { cultural adjustment issues are } \\
\text { not covered. }\end{array}$ \\
\hline
\end{tabular}

\section{CONCLUSION}

$\mathrm{CQ}$ is one domain of intelligence that involves a general set of capabilities with relevance to situations characterized by cultural diversity. It shares some attributes with EQ, SQ and personality, yet is distinct in the nature of abilities from, personality and other forms of intelligence in that CQ is innately culture-free. The four dimensions that conceptualize CQ are meta-cognition, cognition, motivation and behaviour. The four-dimensional CQ model has been shown to perform well in research studies. Specifically, meta-cognitive CQ reflects the higher level mental capability to acquire and understand cultural knowledge. The second cognitive facet of CQ reflects the learned or procedural cultural knowledge and knowledge structures about culture. The third motivational element acknowledges that most cognition is motivated and reflects individual capability to direct energy towards learning about and functioning in intercultural situations. Finally, behavioural CQ is the capability to exhibit appropriate verbal and nonverbal behaviours during cross-cultural interaction. Prior empirical studies have indicated that the CQ construct adequately predicts cultural judgment, decision-making and task performance [32], cultural adaptation [32]; Williams, 2008; Ramalu, 2011), cross-cultural experiences and need for control [39], multi-cultural teams in cross-border business [40], and international non-work experiences and workplace culture [41]. The understanding of the significance of the CQ conceptualization in diverse cultural environments still remains at an early stage [42]; therefore there is considerable room for researchers to explore the relationship between the different dimensions of CQ and its effective measurement.

\section{ACKNOWLEDGMENT}

Funding for this research was provided by National Natural Science Foundation of China under grants 71762033. The facilitation from international collaborative program and cooperation with Charles Sturt University in Australia is gratefully acknowledged. The assistance of Dr. Eshref Trushin, Professor Mark Frost and Antony Bush and comments from an associate editor and two anonymous reviewers are also acknowledged.

\section{REFERENCES}

[1] S. Stryker, "Identity theory: Developments and extensions," In K. Yardley and T. Honess (Eds.), Self and identity: Psychosocial perspectives, London: Wiley, 1987, pp. 89-103.

[2] L. Nardon, and R. Steers, "The culture theory jungle: Divergence and convergence in models of national culture," In R. S. Bhagat and R. M. Steers (Eds.), Cambridge handbook of culture, organizations, and work, Cambridge: Cambridge University Press, 2009, pp. 3-11.

[3] A. Bandura, "Social learning theory. Englewood Cliffs," NJ: Prentice Hall, 1997.

[4] A. Bandura, "Social foundations of thoughts and actions: A social cognitive theory," Englewood Cliffs, NJ: Prentice Hall, 1986.

[5] A. Bandura, "Social cognitive theory in cultural context," Applied Psychology: An International Review, vol. 51, 2002, pp. 269-290.

[6] E.C. Butterfield, "Metacognition. In R. J. Sternberg (Ed.), Encyclopedia of human intelligence," New York: Macmillan, 1994, pp. 725-732.

[7] J.E. Davidson, R. Deuser, and R.J. Sternberg, "The role of metacognition in problem solving. In J. Metcalf and A. P. Shimamura (Eds.), Metacognition: Knowing about knowing, Cambridge, MA: MIT Press, 1995, pp. 207-226.

[8] C. Earley, "Redefining interactions across cultures and organizations Moving forward with cultural intelligence," Research in Organizational Behavior, vol. 24, 2002, pp. 271-299. 
[9] C. Earley, and S. Ang, "Cultural intelligence: Individual interactions across cultures," Stanford, CA: Stanford University Press, 2003.

[10] C. Earley, S. Ang, and J.S. Tang, "Cultural intelligence," European Business Forum (20), 2005

[11] C. Earley, and C.B. Gibson, "Multinational work teams: A new perspective,' Hillsdale, NJ: Lawrence Erlbaum, 2000.

[12] C. Earley, and E. Mosakowski, "Cultural Intelligence," Harvard Business Review, vol. 82, 2004, pp. 139-146.

[13] C. Earley, and R.S. Peterson, "The elusive cultural chameleon: Cultural intelligence as a new approach to intercultural training for the global manager," Academy of Management Learning and Education, vol. 3, 2004, pp. 100-115.

[14] M. Erez, and P.C. Earley, "Culture, self-identit and work," New York: Oxford University Press, 1993.

[15] L. Gottfredson, "Highly general and highly practical. In R. J. Sternberg and E. L. Grigorenko (Eds.)," The general factor of intelligence: How general is it. Mahwah, NJ: Lawrence Erlbaum Associates, 2002, pp. 331-380.

[16] R. House, D.M. Rousseau, and M. Thomas-Hunt, "The meso paradigm: A framework for the integration of micro and macro organizational behavior," Research in organizational behavior. Greenwich, CT: JAI Press, vol. 17, 1995, pp. 71-114.

[17] C.H. Hui, and H.C. Triandis, "Measurement in cross-cultural psychology: A review and comparison of strategies," Journal of Crosscultural Psychology, vol. 16, 1985, pp. 131-152.

[18] K.Y. Ng, and C. Earley, "Culture and intelligence: Old constructs," new frontiers. Group and Organization Management, vol. 31, 2006, pp. 4-19.

[19] R.J. Sternberg, 'International handbook of intelligence,' Cambridge, UK: Cambridge University Press, 2004.

[20] R.J. Sternberg, and D.K. Detterman, "What is intelligence? Contemporary viewpoints on its nature and definition," Norwood, NJ: Ablex, 1986.

[21] D.C. Thomas, and K. Inkson, "Cultural intelligence: People skills for global business," San Francisco, CA: Berrett-Koehler, 2004.

[22] D.C. Thomas, and E.C. Ravlin, "Responses of employees to cultural adaptation by a foreign manager," Journal of Applied Psychology, vol. 80, 1995, pp. 133-146

[23] D.C. Thomas, G. Stahl, E.C. Ravlin, S. Poelmans, A. Pekerti, and K. $\mathrm{Au}$, "Culture and intelligence: Domain and assessment," International Journal of Cross Cultural Management, vol. 8, 2008, pp. 123-143.

[24] H. Triandis, "The self and social behavior in differing cultural contexts," Psychological Review, vol. 96, 1989, pp. 506-520.

[25] H. Triandis, "Culture and social behavior," New York: McGraw Hill, 1994.

[26] J.C. Nunnally, and I.H. Bernstein, "Psychometric theory," New York: McGraw-Hill, 1994
[27] H. Marlowe, "Social intelligence: Evidence for multidimensionality and construct independence," Journal of Educational Psychology, vol. 78, 1986, pp. 52-58

[28] J. Block, "A contrarian view of the five-factor approach to personality description," Psychological Bulletin, vol. 117, 1995, pp. 187-215.

[29] R.R. McCrae, and P.T. Costa, "Validation of the five-factor model of personality across instruments and observers," Journal of Personality and Social Psychology, vol. 52, 1987, pp.81-90.

[30] S. Ang, and A.C. Inkpen, "Cultural intelligence and offshore outsourcing success: A framework of firm-level intercultural capability," Decision Sciences, vol. 39, 2008, pp. 337-358.

[31] S. Ang, L. VanDyne, and C. Koh, "Personality correlates of the fourfactor model of cultural intelligence," Group and Organization Management, vol. 31, 2006, pp. 100-123.

[32] S. Ang, L. VanDyne, and C. Koh, K.Y. Ng, K.J. Templer, C. Tay, and N.A. Chandrasekar, "Cultural intelligence: Its measurement and effects on cultural judgment and decision making, cultural adaptation and task performance," Management and Organization Review, vol. 3, 2007, pp. 335-371.

[33] S. Ang, L. VanDyne, and C. Koh, and K.Y. Ng, "The measurement of cultural intelligence," Paper presented at the Academy of Management Meeting's Symposium on Cultural Intelligence in the 21st Century, New Orleans, 2004.

[34] D. Goleman, "Emotional intelligence," New York: Bantam Books, 1995.

[35] J.F. Kihlstrom, and N. Cantor, "Social intelligence," New York: Cambridge University Press, 2000.

[36] J.H. Flavell, "Metacognition and cognition monitoring: A new area of cognitive inquiry," American Psychologist, vol. 34, 1979, pp. 06-911.

[37] E.A. Locke, and P.G. Latham, "A theory of goal setting and task performance," Englewood Cliffs, NJ: Prentice-Hall, 1990.

[38] C. Hampden-Turner, and F. Trompenaars, "Cultural intelligence: Is such a capacity credible?" Group and Organization Management, vol. 31, 2006, pp. 56-63.

[39] C. Tay, M. Westman, A. and Chia, "Antecedents and consequences of cultural intelligence among short-term business travelers," Handbook on cultural intelligence: Theory, measurement and applications. Armonk, NY: M.E. Sharpe, 2008, pp. 126-144.

[40] E. Shokef, and M. Erez, "Handbook on cultural intelligence: Theory, measurement and applications," Armonk, NY: M.E. Sharpe, 2008, pp. 16-38.

[41] A. Balogh, Z. Gall, and L. Szabo, "Relationship between organizational culture and cultural intelligence," Management and Marketing Challenges for the Knowledge Society, vol. 6, 2011, pp. 95-110.

[42] S.A.L.S. Ramalu, C.W. Chuah, and R.C. Rose, "The effects of cultural intelligence on cross-cultural adjustment and job performance amongst expatriates in Malaysia," International Journal of Business \& Social Science, vol. 2, 2011, pp. 59-71 